\title{
ANALISIS KELAYAKAN BUKU TEKS BAHASA INDONESIA MAHIR BERBAHASA INDONESIA (MARBI) KELAS VII EDISI REVISI
}

\author{
Siti Risna Nur Alviya ${ }^{1}$, Indrya Mulyaningsih ${ }^{2}$, Emah Khuzaemah ${ }^{3}$ \\ IAIN Syekh Nurjati Cirebon
}

Email: sitirisna06@gmail.com ${ }^{1}$,indrya.m@gmail.com ${ }^{2}$, emah_kh@yahoo.co.id ${ }^{3}$

\begin{abstract}
Abstak: Penelitian ini bertujuan untuk mengetahui kelayakan buku teks Bahasa Indonesia Mahir Berbahasa Indonesia (MARBI) kelas VII edisi revisi. Penilaian aspek kelayakan buku teks berdasarkan standar BSNP dengan menganalisis empat kelayakan yang meliputi kelayakan isi, kelayakan kebahasaan, kelayakan penyajian, dan kelayakan kegrafikan. Penelitian ini termasuk ke dalam penelitian kualitatif deskriptif. Sumber data penelitian ini adalah pendapat guru bahasa Indonesia yang pernah menggunakan buku teks tersebut dan buku teks MARBI untuk kelas VII edisi revisi. Data dalam penelitian ini adalah unit tekstual dan unit nontekstual. Teknik pengumpulan data dengan analisis dokumen, wawancara, dan grafik fry. Instrumen pengumpulan data yang digunakan adalah lembar penilaian berdasarkan BSNP, pedoman wawancara, dan grafik fry. Keabsahan data dalam penelitian ini diperoleh dari triangulasi sumber data, triangulasi teori, dan triangulasi metode pengumpulan data. Analisis data dilakukan secara interaktif dengan prosedur reduksi data, penyajian data, dan penarikan kesimpulan/verifikasi. Hasil analisis kelayakan buku teks MARBI ialah kelayakan isi/materi dengan nilai $76,62 \%$; 2) kelayakan kebahasaan dengan nilai $82,85 \%$; 3) kelayakan penyajian dengan nilai 83,33\%; dan 4) kelayakan kegrafikan dengan nilai $82,61 \%$. Kelayakan tersebut masiih butuh bimbingan dari pendidik.
\end{abstract}

Kata kunci: Analisis, Kelayakan buku teks, Standar BSNP

\section{FEASIBILITY ANALYSIS OF INDONESIAN TEXT BOOKS MAHIR LANGUAGE INDONESIA (MARBI) CLASS VII REVISION EDITION}

\begin{abstract}
This study aims to determine the feasibility of the revised edition of the revised edition of the Indonesian Advanced Bahasa Indonesia (MARBI) textbook. The assessment of the feasibility of a textbook is based on BSNP standards by analyzing four feasibility including content feasibility, linguistic feasibility, presentation feasibility, and graphic feasibility. This research is included in descriptive qualitative research. The data source of this research is the opinion of the Indonesian language teacher who has used the textbook and the revised edition of the MARBI textbook for grade VII. The data in this study are textual units and non-textual units. Data collection techniques with document analysis, interviews, and fry charts. The data collection instruments used were assessment sheets based on the BSNP, interview guidelines, and fry charts. The validity of the data in this study was obtained from the triangulation of data sources, triangulation of theories, and triangulation of data collection methods. Data analysis was performed interactively with data reduction procedures, data presentation, and drawing conclusions / verification. The results of the feasibility analysis of the MARBI textbook were the content / material feasibility with a value of $76.62 \%$; 2) linguistic feasibility with a value of $82.85 \%$; 3) the feasibility of serving with a value of $83.33 \%$; and 4) the feasibility of the graphics with a value of $82.61 \%$. This feasibility still needs guidance from educators.
\end{abstract}

BASASTRA Jurnal Bahasa, Sastra, dan Pengajarannya

Volume 8 Nomor 2, Oktober 2020, P-ISSN 2302-6405, E-ISSN 2714-9765 
Keywords: Analysis, Textbook Feasibility, BSNP Standards

\section{PENDAHULUAN}

Pendidikan adalah salah satu yang memengaruhi kualitas sumber daya manusia. manusia saling berlomba untuk mengetahui kemampuannya melalui belajar. Dalam belajar tentunya manusia membutuhkan sesuatu yang dapat dijadikan bahan rujukan atau sumber belajar untuk mencapai tujuan yang diinginkan. Sumber belajar bisa dari guru, buku, atau sumber lainnya.

Komponen mutlak yang diperlukan guru dan siswa yaitu buku pelajaran atau buku teks pelajaran. Setiap mata pelajaran memerlukan buku teks sebagai penunjang keberhasilan dalam belajar khususnya pada pembelajaran bahasa Indonesia. Pembelajaran Bahasa Indonesia dari mulai tingkat SD (Sekolah Dasar) sampai SMA/SMK menggunakan pembelajaan berbasis teks (Mahsun, 2014: 95). Penentu keberhasilan pembelajaran bahasa menurut Tarigan (2009: 2) yakni (1) pembelajar bahasa, ditentukan oleh motivasi, relevansi, dan harapan pembelajar; (2) pengajar bahasa, ditentukan oleh kompetensi profesionalitas, penghargaan terhadap pembelajar, dan motivasi penegajar; dan (3) sistem pengajaran, ditentukan oleh tujuan yang realitas, sarana yang baik, intensitas pengajaran yang tinggi, dan kurikulum yang tepat. Sebagai sarana belajar, tentunya buku teks harus mudah dipahami baik oleh pengajar atau pelajar. Bahasa dalam buku teks adalah salah satu faktor yang dapat menentukan misi sebagai penunjang utama dalam pembelajaran (Kairil, Salam, \& Junus, 2016: 34).

Sebelum menulis buku teks harus memahami terlebih dahulu lima landasan penulisan buku teks meliputi 1) landasan keilmuan; 2) landasan ilmu pendidikan dan keguruan; 3) landasan kebutuhan siswa; dan 4) landasan keterbacaan materi dan bahasa yang digunakan( Muslich, 2016: 133-169).

Salah satu yang perlu dievalusi dalam buku teks pelajaran yaitu kualitas buku tersebut. Menginat informasi dalam buku sangat penting untuk melancarkan proses penyaluran ilmu dalam pembelajaran. Pada dasarnya ada dua faktor yang memengaruhi pemahaman seseorang terhadap buku teks yakni faktor pembaca dengan latar belakang (pengetahuan,motivasi, kematangan, dan kecerdasan) dan dari bahan (faktor cetakan, konsep, ilustrasi, dan kalimat) (Arif et al., 2016: 317). Buku teks tersebut dianggap adanya kesulitan oleh siswa kemudian dilihat dari hasil jawaban soal bacaan

BASASTRA Jurnal Bahasa, Sastra, dan Pengajarannya

Volume 8 Nomor 2, Oktober 2020, P-ISSN 2302-6405, E-ISSN 2714-9765 
menunjukkan nilai yang jelek. Dengan demikian penelitian ini dibuat untuk menganalisis kelayakan buku Mahir Berbahasa Indonesia (MARBI) kelas VII edisi revisi berdasarkan standar BSNP yakni kelayakan isi, kelayakan kebahasaan, kelayakan penyajian, dan kelayakan kegrafikan.

\section{METODE}

Penelitian ini bersifat penelitian kualitatif, penelitian kualitatif ini menggunakan pendekatan deskriptif. Penelitian kualitatif adalah penelitian yang memahami suatu fenomena yang dialami oleh subjek dan dideskripsikan melalui kata-kata (Tohirin, 2013: 3). Pendekatan deskriptif adalah metode penelitian yang dilakukan untuk mengetahui sifat dan hubungan yang lebih mendalam mengenai dua variabel dengan cara mengamati aspek-aspek tertentu secara spesifik untuk mendapatkan data yang sesuai dengan masalah yang ada (Sugiyono, 2017: 35). Melalui pendekatan tersebut akan dijelaskan mengenai kelayakan buku teks MARBI (Mahir Berbahasa Indonesia) kelas VII edisi revisi.

Data dalam penelitian ini adalah unit tekstual berupa paparan verbal (frasa, klausa, kalimat, paragraf, dan wacana) dan unit nontekstual (gambar, tabel, bagan, layout, warna, dan ukuran). Sumber data penelitian ini adalah buku teks MARBI (Mahir Berbahasa Indonesia) untuk kelas VII edisi revisi yang disusun oleh Wahono, Mafrukhi, dan
Sawali. Teknik pengumpulan data dilakukan dengan wawancara, analisis dokumentasi, dan grafik fry untuk aspek keterbacaan. Wawancara dilakukan dengan tidak terstruktur untuk mendapatkan pendapat guru bahasa Indonesia mengenai buku teks MARBI. Wawancara tidak terstruktur yakni wawancara yang dilakukan dengan tujuan mendapat informasi bukan baku atau bukan informasi tunggal (Nugrahani, 2014: 127).

Instrumen adalah suatu alat yang digunakan untuk mengumpulkan data (Sugiyono, 2017: 102). Instrumen pengumpulan data dalam penelitian ini berupa lembar penilaian berdasarkan standar BSNP, pedoman wawancara, dan grafik Fry. Lembar penilaian tersebut mengacu pada standar kelayakan yang ditetapkan oleh BSNP dan Pusat Perbukuan Depdiknas. Grafik Fry diperkenalkan oleh Edward Fry untuk menentukan tingkat keterbacaan dengan mempertimbangkan panjang pendeknya kata dan tingkat kesulitannya yang ditandai oleh jumlah suku kata (Nurlaili, 2011: 171). Prosedur penggunaan grafik Fry menurut Forgan dan Mangrum II (dalam Abidin, 2015: 217), meliputi (a) memilih wacana yang memiliki panjang kurang lebih seratus kata; (b) menghitung jumlah kalimat dalam penggalan yang terdiri dari seratus kata; (c) menghitung jumlah suku kata per seratus kata; (d) mengalikan hasil perhitungan suku kata dengan angka 0,6; (e) mencocokan rumus jumlah 
kalimat dan jumlah suku kata per seratus tersebut dalam grafik Fry; dan (f) menetapkan tingkat keterbacaan. Dalam penelitian ini untuk menjamin keabsahan data digunakan teknik triangulasi. Triangulasi merupakan teknik pemeriksa keabsahan data dengan memnfaatkan sesuatu yang di luar data itu sendiri, sebagai bahan pengecekan atau perbandingan terhadap data (Bachri, 2010: 56). Macam-macam triangulasi, yaitu: 1) triangulasi sumber; 2) triangulasi waktu; 3) triangulasi teori; 4) triangulasi peneliti; dan 5) triangulasi metode.Dalam penelitian ini untuk menjamin keabsahan data digunakan teknik triangulasi. Triangulasi merupakan teknik pemeriksa keabsahan data dengan memnfaatkan sesuatu yang di luar data itu sendiri, sebagai bahan pengecekan atau perbandingan terhadap data (Bachri, 2010: 56). Macam-macam triangulasi, yaitu: 1) triangulasi sumber; 2) triangulasi waktu; 3) triangulasi teori; 4) triangulasi peneliti; dan 5) triangulasi metode.

Dalam penelitian ini triangulasi yang digunakan adalah triangulasi sumber data, triangulasi teori, dan triangulasi metode. Triangulasi sumber data digunakan untuk melakukan pengecekan terhadap data dengan memanfaatkan sumber lain sebagai pembanding. Sementara itu, triangulasi teori dengan memanfaatkan dua teori atau lebih untuk menerjemahkan data atau informasi yang didapatkan. Sedangkan triangulasi metode pengumpulan data dilakukan dengan menggunakan beberapa teknik pengumpulan data untuk mendapatkan data. Menganalisis data hasil penelitian dengan menggunakan analisis model interaktif Miles dan Huberman. Analisis dilakukan secara interaktif dan berlangsung secara terus-menerus sampai jenuh. Miles dan Huberman (1992) (dalam Suharsaputra, 2012: 218) mengemukakan bahwa analisis interaktif meliputi tiga komponen yaitu (1) reduksi data; (2) sajian data; dan (3) penarikan simpulan/verifikasi.

\section{HASIL DAN PEMBAHASAN}

\section{Hasil Analisis Kelayakan Buku Teks Berdasarkan Standar BSNP}

Analisis kelayakan buku teks MARBI difokuskan pada empat kelayakan meliputi kelayakan isi/materi, kelayakan kebahasaan, kelayakan penyajian, dan kelayakan kegrafikan. Analisis kelayakan berdasarkan beberapa aspek, yaitu:

Kelayakan isi/materi dengan nilai 76,62\%.

Hal ini difokuskan pada tiga sub komponen yakni kesesuaian uraian materi dengan $\mathrm{KI}$ dan $\mathrm{KD}$, keakuratan materi, dan pendukung materi pembelajaran. Butir komponen pada setiap sub kompunen meliputi kelengkapan materi, kedalaman materi, keakuratan (konsep, uraian dan pelatihan), kesesuaian (contoh, fitur, dan pelatihan), pengembangan (penalaran dan pembuktian), 
keterkaiatan antar konsep/tabel, komunikasi, pembudayaan literasi, pengembangan wawasan (kebhinekaan, kebangsaan, dan integrasi), kode etik penulisan, dan bebas unsur SARA.

(a) Kelengkapan materi, hasil analisis bahwa buku teks MARBI telah dilengkapi wacana, pemahaman wacana, fakta kebahasaan dan kesastraan. Setiap bab dilengkapi dengan fakta kebahasaan. Namun hanya bab 7 yang dilengkapi fakta kebahasaan dan kesastraan. Fakta kesastraan tersebut hanya muncul pada pembelajaran puisi rakyat. Buku teks MARBI telah dilengkapi pelatihan berupa tugas sebagai bentuk upaya untuk membantu peserta didik memahami isi dan struktur wacana.

(b) Kedalaman materi, Hasil analisis bahwa buku teks MARBI memuat wacana yang sesuai dengan pemahaman peserta didik dengan mengangkat tema-tema yang sesuai dengan KD. Namun, kuantitas wacana masih kurang karena terdapat sebagian kecil teks yang tidak memiliki gambar atau ilustrasi sebagai penjelas. Mengingat tidak semua peserta didik memahami teks dengan baik tentu perlu alat (gambar) sebagai sarana membantu peserta didik memahami isi dari teks tersebut. Hal ini terlihat pada bab 4 bagian subbab B "Menyimpulkan isi Teks Laporan Hasil Observasi" terdapat teks dengan judul "Eceng Gondok". Selain itu pada subbab C "Menelaah Struktur, Kebahasaan, dan Isi Teks Laporan Hasil Observasi" terdapat teks dengan judul "Pupuk Organik". Selanjutnya masih di bab 4 subbab C pada aktivitas 5 atau tugas terdapat teks dengan judul "Ketela Pohon". Aktivitas 7 pada subbab D "Menyajikan Rangkuman Teks Laporan Hasil Observasi" terdapat teks dengan judul "Jati" serta pada uji kompetensi terdapat teks yang tidak myertakan gambar. Sebaiknya diberikan gambar sebagai penjelas sehingga dapat membantu siswa dalam memahami teks tersebut. Kualitas wacana pada buku MARBI cukup bervariasi dan mutakhir.

(c) Keakuratan konsep, uraian, dan pelatihan, konsep yang disajikan sesuai bidang keilmuan bahasa Indonesia. Pelatihan atau tugas sesuai dengan penilaian autentik dan memuat soal-soal yang mengukur penguasaan pengetahuan, yakni dengan menggunakan tes tulis, tes lisan, dan penugasan. Penggunaan tes tulis dan penugasan lebih dominan dibandingkan dengan tes lisan sehingga terkesan kurang seimbang. Dalam hal ini diharapkan harus menyelaraskan antara tes tulis, tes lisan, dan penugasan. 
(d) Kesesuain contoh, fitur, dan pelatihan, hasil analisis buku teks MARBI memuat contoh, fitur, dan pelatihan yang mencerminkan peristiwa dan kejadian di Indonesia. Dengan demikian, hal tersebut dapat melestarikan nilai falsafah yang berlaku di Indonesia.

(e) Pengembangan penalaran dan pembuktian, Sebagai bentuk pembuktian dan penalaran dalam buku MARBI terdapat sosl-soal latihan. Soal-soal yang disajikakan memiliki tingkat kesulitan yang bervariasi. Namun, terdapat sedikit pengulangan dan persamaan perintah atara tugas individu dengan tugas kelompok. Sedangkan untuk materi yang disajikan runtut tidak tumpang tindih.

(f) Keterkaitan antarkonsep/tabel, hasil analisis buku teks MARBI memiliki keterkaitan antarkonsep/tabel. Namun, dalam buku MARBI terdapat tugas yang tidak sesuai dengan perintah. Misalnya pada aktivitas 4 di bab 3 mengenai teks prosedur di sana terdapat perintah "Bentuklah kelompok yang terdiri atas lima orang. Bagilah tugas untuk melengkapi tabel berikut. ....". Perintah tersebut meminta peserta didik untuk melengkapi tabel, akan tetapi tabel yang dimaksud tidak tercetak dalam aktivitas tersebut sehingga tidak ada keterkaiatan antar konsep dan tabel yang dimaksudkan.

(g) Komunikasi, Buku teks MARBI sudah menstimulus peserta didik untuk mengomunikasikan ide baik secara tulis maupun lisan (individu, berpasangan, atau berkelompok). Setiap penugasan peserta didik diminta untuk menulis, kemudian hasil penulisan dipresentasikan di depan kelas sedangkan peserta didik yang lain memberikan tanggapan terhadapan penampilan peserta didik yang telah presentsi.

(h) Pembudayaan literasi, buku teks MARBI lebih fokus pada literasi kritikal yang dapat terlihat dari setiap penugasan selalu berkaitan dengan analisis teks. Dari 8 bab yang menugaskan mencari informasi dari sumber lain hanya 2 bab yaitu bab 4 dan 8 . Dengan demikian, buku teks MARBI masih kurang memotivasi peserta didik untuk mencari informasi lain dari berbagai sumber sebagai bentuk pembudayaan literasi.

(i) Pengembangan wawasan (kebhinekaan, kebangsaan, dan integrasi), buku teks MARBI cukup baik dalam mengembangkan wawasan kebhinekaan. Hal ini dapat dilihat dari penggunaan wacana dengan tema peninggalan sejarah, adat istiadat, alat musik, dan makanan khas Indonesia. Namun untuk rasa bangga menggunakan bahasa Indonesia masih kurang. 
Seharusnya itu menjadi hal utama dalam materi pembelajaran bahasa Indonesia.

(j) Kode etik penulisan dan hak cipta, dalam buku teks MARBI ditemukan beberapa gambar dan kutipan wacana tanpa sumber yang jelas. Padahal seharusnya itu hal penting yang harus dicantumkan. Dengan demikian, perlu adanya perbaikan untuk mencantumkan sumber gambar yang jelas.

(k) Tidak mengandung unsur SARA, HAKI, Pornografi, dan Bias (gender, wilayah, dsb), buku teks MARBI bebas unsur SARA, HAKI, pornografi, dan bias (gender, wilayah, dsb). Dengan demikian, buku teks sangat sesuai dengan indikator penilaian yang menyatakan bahwa materi tidak menimbulkan masalah suku, agama, ras, SARA, dan pornografi.

Kelayakan kebahasaan dengan nilai $82,85 \%$.

Hal ini difokuskan pada tiga sub komponen yakni kesesuaian dengan tingkat perkembangan peserta didik, komunikatif, dan keruntutan dan kesatuan gagasan. Butir komponen pada setiap subkomponen kelayakan kebahasaan meliputi kesesuaian dengan tingkat perkembangan (intelektual dan sosial emosional) peserta didik, tingkat keterbacaan, ketepatan bahasa, dan keruntutan serta keterpaduan (subbab, paragraf, dan kalimat). (a) Kesesuaian dengan tingkat perkembangan intelektual dan sosial emosional peserta didik, buku teks MARBI untuk menjelaskan konsep, wacana, dan ilustrasi sesuai dengan perkembangan intelektual peserta didik. Namun, masih ada konsep yang masih abstrak. Salah satunya pada konsep yang menjelaskan tentang "teknik pengarang dalam menggambarkan watak tokoh dalam cerita" pada subbab "Menelaah Struktur dan Kebahasaan Teks Fabel". Selain itu, juga terdapat pada konsep penjelasan "tata kalimat" yang menjelaskan tentang kalimat efektif. Hal tersebut masih abstrak sehingga secara imajinatif belum dapat dibayangkan oleh peserta didik. Bahasa yang digunakan dalam wacana, teks, ilustrasi, telah sesuai dengan perkembangan sosial emosional peserta didik. Hal tersebut ditandai dengan penggambaran konsep yang dimulai dari lingkungan terdekat (sekolah) sampai lingkungan global (Negara).

(b) Tingkat keterbacaan, hasil pengukuran keterbacaan buku teks MARBI berdasarkan prosedur grafik Fry dari sembilan teks bacaan yang diambil dibagian awal, tengah, dan akhir adalah satu sampel dengan kriteria mudah, enam sampel dengan kriteria sesuai, dan dua sampel 
dengan kriteria sukar. Dengan demikian tingkat keterbaacaan sesuai dengan peserta didik. Namun demikian, untuk teks dengan kategori sulit dan mudah dapat diganti atau direvisi dengan teks lain yang sesuai dengan peserta didik kelas VII.

(c) Ketepatan bahasa, penulisan buku teks MARBI sesuai dengan kaidah kebahasaan yang berlaku. Kalimat yang digunakan efektif, terdapat kesesuaian pengggunaan kata atau istilah dalam menyampaikan gagasan. Bahasa yang digunakan dialogis dan interaktif, seolah peserta didik berbicara dengan penulis sehingga terdapat upaya mendorong peserta didik untuk mempelajari buku secara tuntas.

(d) Keruntutan dan keterpaduan (subbab, paragraf, kalimat), Buku teks MARBI memiliki keruntutan dan keterpaduan baik subbab, paragraf, maupun kalimat. Hal ini ditandai dengan penyampaian pesan melalui wacana, gambar, ilustrasi baik antarsubbab maupun antarparagrf mencerminkan hubungan yang logis. Dengan demikian, keruntutan dan keterpaduan baik subbab, paragraf, maupun kalimat sesuai dengan indikator penilaian.

\section{Kelayakan penyajian dengan nilai $83,33 \%$.}

Kelayakan penyajian adalah menguraikan materi pembelajaran dengan aspek-aspek lain yang berlaku. Penyajian buku teks dapat memengaruhi minat baca dan keterbacaan buku teks (Astuti et al., 2017). Penyajian buku teks hendaknya memuat contoh-contoh yang dekat dengan kehidupan sehari-hari sehingga dapat merangsang siswa untuk mengaplikasikan pengetahuan yang diperolehnya (Rofi et al., 2014). Hal ini difokuskan pada tiga sub komponen yakni teknik penyajian, penyajian pembelajaran, dan kelengkapan penyajian. Butir komponen dari setiap sub komponen kelyakan penyajian meliputi penyajian (konsisten, runtut, dan seimbang), pembelajaran berpusat pada peserta didik, merangsang metakognisi imajinasi, dan kreasi peserta didik, dan Kelengkapan bagian (pendahuluan, isi, dan penutup).

(a) Konsistensi, keruntutan, dan keseimbangan penyajian, Buku teks MARBI memiliki konsistensi sistematika penyajian yaitu adanya motivasi pembangkit semangat yang disajikan dengan uraian. Selain itu terdapat bagian pendahuluan yang berisi uraian pengantar materi dan bagian isi berupa materi sesuai dengan KIKD. Keruntutan penyajian buku teks MARBI terdapat pada setiap bab yang menyajikan konsep atau teori (wacana) yang diikuti penerapan (latihan). Bagian akhir

BASASTRA Jurnal Bahasa, Sastra, dan Pengajarannya

Volume 8 Nomor 2, Oktober 2020, P-ISSN 2302-6405, E-ISSN 2714-9765 
terdapat uji kompotensi sebagai bahan evaluasi. Buku teks MARBI tidak memiliki halaman yang seimbang pada setiap babnya. Buku teks MARBI memiliki 280 halaman dengan jumlah bab yaitu 8, 2 UAS (ulangan akhir semester). Jumlah halaman bab 1 ialah 40 . Jumlah halaman bab 2 ialah 28 . Jumlah halaman bab 3 ialah 18 . Jumlah halaman bab 4 ialah 34 . Jumlah ulangan akhir semester 1 ialah 17. Jumlah halaman bab 5 ialah 32. Jumlah halaman bab 6 ialah 26. Jumlah halaman bab 7 ialah 22. Jumlah halaman bab 8 ialah 42. Jumlah halaman ulangan akhir semester 2 ialah 20. Ketidak seimbangan tersebut dipengaruhi oleh perbedaan dalam kelengkapan dan kedalaman materi, wacana, tugas, tabel, gambar, serta uji kompetensi pada setiap bab.

(b) Pembelajaran berpusat pada peserta didik, Penyajian buku teks MARBI telah menempatkan peserta didik sebagai subjek atau pusat pembelajaran melalui aktivitas yang berorientasi ilmiah yaitu pembelajaran kooperatif atau kerja sama (Cooperative Learning), penemuan (Discovery/ Inquiry Learning), dan proyek (project based learning). Selain itu, materi yang disajikan dalam buku teks MARBI bersifat interaktif dan partisipatif dalam pencapaian KI dan KD. Hal tersebut dapat ditandai dengan adanya tugas yakni tugas individu, berpasangan, dan kelompok.

(c) Merangsang metakognisi, imajinasi, dan kreasi peserta didik, Buku teks MARBI dapat merangsang metakognisi, imajinasi, dan kreasi melalui analisis teks, latihan pada setiap bab, dan ilustrasi yang disajikan. Penyajian buku teks MARBI telah memuat wacana, gambar, ilustrasi, dan latihan yang dapat merangsang metakognisi peserta didik. Selain merangsang metakognisi juga membangkitkan motivasi untuk menggali rasa ingin tahu dan berkreasi sesuai imajinasi peserta didik.

(d) Kelengkapan bagian (pendahuluan, isi, dan penutup), buku teks MARBI telah memuat 1) pada bagian pendahuluan terdapat kata pengantar dan daftar isi; 2) Bagian awal isi terdapat pendahuluan yang berisi tujuan pembelajaran dan peta konsep; 3) Bagian isi keseluruhan berisi materi berdasarkan KI-KD; 4) Bagian evaluasi yang mampu mengaplikasikan konsep keilmuan sesuai dengan pokok bahasan; 5) bagian penutup berisi daftar pustakan. Kekurangannya tidak terdapat glosarium sebagai penerjemah istilah-istilah untuk memudahkan pemahaman.

Kelayakan kegrafikan dengan nilai $82,61 \%$.

Ilmu grafika merupakan cabang ilmu desain yang mengkaji 
presentasi visual media atau buku teks dengan memanfaatkan rupa atau elemen-elemen visual dapat berupa gambar, simbol, ilustrasi, dan teks (Arifin et al., 2009). Hal ini difokuskan pada tiga sub komponen yakni ukuran buku, desain sampul buku, dan desain isi buku. Butir komponen dari setiap subkomponen kelayakan kegrafikan meliputi ukuran buku, komposisi warna sampul buku , tata letak (sampul dan isi) buku, tipografi (sampul dan isi) buku, ilustrasi (sampul dan isi) buku, dan susunan teks.

(a) Ukuran buku teks MARBI sangat sesuai dengan indikator butir komponen yakni Kesesuaian ukuran buku dengan standar ISO: A4 (210 X 297) atau B5 (176 X 250). Buku teks MARBI memiliki ukuran 176 X $250 \mathrm{~mm}$ sesuai dengan standar yang telah ditentukan.

(b) memiliki kesatuan. Namun, warna latar yang digunakan tidak sesuai antara bagian depan dengan belakang. Bagian depan berwarna latar putih sedangkan bagian belakang berwarna abu-abu. Tata letak antara judul, ilustrasi, nama penulis, dan nama penerbit cukup seimbang. Sampul buku teks MARBI pusat pandang yang jelas yakni Marbi seabagai judul utama, Mahir Berbahasa Indonesia sebagai anak judul, ilustrasi, nama penulis, dan penerbit.

(c) Tipografi sampul buku, ukuran dan jenis huruf yang digunakan pada judul utama berbeda dengan anak judul dan nama penulis. Penulisan kata "Indonesi" pada anak judul lebih ditonjolkan sehingga mampu menjelaskan tentang pelajaran yang dibahas dalam buku teks MARBI. Kombinasi warna yang digunakan kontras dengan latar belakang sampul.

(d) Ilustrasi sampul pada buku MARBI yakni kotak surat yang terbuka berwarna merah dilengkapi 5 amplop surat berwarna putih. Objek yang ditampilkan konkret (jelas) dan selaras dengan ukuran tulisan. Namun, ilustrasi tersebut kurang menarik siswa untuk mau membaca. Ilustrasi buku kurang menjelaskan karakter isi buku.

(e) Komposisi warna yang digunakan pada sampul buku teks MARBI memiliki detail tajam dan jelas, namun tata warna yang digunakan kurang estetis.

(f) Tata letak isi buku teks MARBI memiliki konsistensi antara bagian depan, isi (pokok bahasan), dan bagian belakang. Bidang cetak dan marjin yang digunakan proporsional dengan isi buku. Selain itu, buku teks MARBI juga memiliki tata letak yang lengkap meliputi judul bab, sub judul bab, angka halaman, keterangan gambar (caption), dan sumber, serta ruang putih (white space). Dengan demikian, tata letak isi buku teks MARBI sebagian besar sesuai dengan indikator penilian 
sedangkan beberapa gambar perlu mencantumkan sumber yang jelas.

(g) Tipografi isi buku, penggunaan jenis huruf yang sederhana mudah dibaca dan tidak menggunakan huruf hias. Jenis huruf sesuai dengan karakter materi, usia, dan tingkat pendidikan peserta didik. Hierarki judul jelas, konsisten, dan proporsional. Dengan demikian tipografi isi buku teks sesuai dengan indikator penilaian.

(h) Ilustrasi yang terdapat dalam isi buku teks MARBI menarik. Namun, untuk teks deskripsi pada bab 1 tidak terdapat ilustrasi. Seharusnya ilustrasi pada teks deskripsi itu penting sebagai sarana untuk membantu peserta didik memahami maksud isi teks tersebut. Selain bab 1 pada bab 2 sampai 8 sebagian kecil ada yang tidak menggunakan ilustrasi dalam teks yang disajikan. Dengan demikian, ilustrasi yang digunakan dalam buku teks MARBI sebagian besar sesuai indikator penilaian akan tetapi perlu perbaikan untuk menambah ilustrasi pada teks lain yang belum terdapat ilustrasi.

(i) Susunan teks sesuai dengan indikator yakni paragraf yang terdapat pada buku teks MARBI memiliki susunan teks yang normal dengan susunan hirarki yang proporsional. Selain itu, tidak ditemukan pemenggalan kata pada akhir baris (orphan, widow, block).

\section{Hasil Wawancara dengan Guru}

Berdasarkan pendapat guru Bahasa Indonesia mengenai buku teks MARBI bahwa isi/materi yang terkandung dalam buku teks sudah cukup baik dan sesuai dengan kelas VII. Materi yang disajikan memiliki keruntutan dan kesinambungan yang baik. Selain itu, materi sudah cukup mengikuti perkembangan Ipteks. Namun, untuk kelengkapan masih kurang sehingga masih membutuhkan referensi lain sebagai tambahan.

Pengembangan wawasan (kebhinekaan, kebangsaan, dan integrasi) cukup baik. Namun, masih harus ditingkatkan motivasi untuk melahirkan rasa cinta terhadap bahasa Indonesia. Metode yang digunakan sudah berorientasi ilmiah yang menjadikan peserta didik sebagai pusat dalam pembelajaran. Penggunaan bahasa sesuai dengan kaidah kebahasaan yang berlaku. Selain itu bahasa yang digunakan juga bersifat dua arah sehingga terjalin komunikasi antar penulis dengan peserta didik.

Penugasan dan pelatihan sudah cukup baik dan sesuai dengan peserta didik Namun, masih terdapat beberapa instruksi dalam penugasan atau pelatihan yang masih abstrak sehingga membutuhkan penjelasan yang lebih sederhana lagi. Soal-soal yang disajikan cukup bervariasi dari yang mudah sampai sulit. Selain itu, ilustrasi yang disajikan sangat bermanfaat dalam pembelajaran dan dapat digunakan secara optimal. Namun, masih ada beberapa yang

BASASTRA Jurnal Bahasa, Sastra, dan Pengajarannya

Volume 8 Nomor 2, Oktober 2020, P-ISSN 2302-6405, E-ISSN 2714-9765 
tidak menyajikan ilustrasi. Secara keseluruhan buku teks MARBI kelas VII bebas unsur SARA dan pornografi. Sedangkan untuk desain cukup baik. Namun, kurang menarik untuk siswa gemar membaca.

\section{SIMPULAN}

Berdasarkan hasil analisis data dapat disimpulkan bahwa buku teks MARBI (Mahir Berbahasa Indonesia) kelas VII edisi revisi berpredikat layak dalam hal isi/materi, kebahasaan, penyajian, dan kegrafikan. Namun demikian masih butuh perbaikan dari penulis mengenai beberapa yang masih kurang. Dalam buku teks MARBI masih terdapat beberapa yang sulit untuk dipahami peserta didik, dengan demikian guru perlu memberikan bimbingan intensif untuk peserta didik.

\section{REFERENSI}

Abidin, Y. (2015). Pembelajaran Multiliterasi. Bandung: PT Refika Aditama.

Arif, S., Lubis, F., \& Barus, F. L. (2016). Keterbacaan Buku Teks Bahasa Indonesia Kurikulum 2013 Kelas VII dengan Grafik Raygor. Jurnal Bahasa, 27(4), 315-328.

Arifin, Syamsul, \& Kusrianto, A. (2009). Sukses Menulis Buku Ajar dan Referensi. Jakarta: Grasindo.

Astuti, R. D., Suwandi, S., \& Waluyo, B. (2017). Kelayakan Buku Pelajaran Bahasa Indonesia Kelas X Ekspresi Diri dan
Akademik. Basastra Jurnal Penelitian Bahasa, Sastra Indonesia Dan Pengajarannya, 5(2), 88-103.

Bachri, B. S. (2010). Meyakinkan Validitas Data Melalui

Triangulasi Pada Penelitian Kualitatif. Jurnal Teknologi Pendidikan, 10(1), 46-62.

Badan Standar Nasional Pendidikan dan Pusat Perbukuan. 2014. Instrumen Penilaian Tahap I dan Tahap II Buku Teks Pelajaran Pendidikan Dasar Dan Menengah. . http://bsnpindonesia.org/? $\mathrm{p}=1340$.

Kairil, Salam, \& Junus, A. F. (2016). Keterbacaan Wacana dalam Buku Teks Bahasa Indonesia "Ekspresi Diri dan Akademik" Cetakan Kedua Melalui Cloze Test Siswa Kelas X SMAN 1 Makassar. Jurnal Retorika, 9(1), 33-39.

Mahsun. (2014). Teks dalam Pembelajaran Bahasa Indonesia Kurikulum 2013. Jakarta: RajaGrafindo Persada.

Muslich, M. (2016). Text Book Writing. Jogjakarta: Ar-Ruzz Media.

Nugrahani, F. (2014). Metode Penelitian Kualitatif. Surakarta.

Nurlaili. (2011). Pengukuran Tingkat Keterbacaan Wacana dalam Pelajaran Bahasa Indonesia Kelas 4-6 SD dan Keterpahamannya. Portal Jurnal Universitas Pendidikan Indonesia, Edisi Khusus, (1), 167-177.

Rofi, A., Atmazaki, \& Abdurahman. (2014). Pengembangan Buku Teks Pembelajaran Berbasis Kontekstual dalam Materi Proses 
Morfologis Bahasa Indonesia pada Program Studi Pendidikan Bahasa dan Sastra Indonesia Fakultas Keguruan dan Ilmu Pendidikan Universitas Batanghari Jambi. Jurnal Bahasa, Sastra, Dan Pembelajaran, 2(3), 1-14.

Sugiyono. (2017). Metode Penelitian Kuantitatif, Kualitatif. Bandung: Alfabeta.

Suharsaputra, U. (2012). Metode Penelitian Kuantitatif, Kualitatif, dan Tindakan. Bandung: Refika Aditama.

Tarigan, H. G. (2009). Pengajaran Kompetensi Bahasa. Bandung: Angkasa.

Tohirin. (2013). Metode Penelitian Kualitatif dalam Pendidikan dan Bimbingan Konseling. Jakarta: RajaGrafindo Persada. 